\title{
Periodic Comprehensive Forest Inventory on Production Forest Management in Papua Province
}

\author{
Financio Dorebayo $^{1 *}$, Endang Suhendang ${ }^{2}$, Muhdin $^{2}$ \\ ${ }^{1}$ Graduate School of Bogor Agricultural University, Dramaga Main Road, Campus IPB Dramaga, Bogor, Indonesia 16680 \\ ${ }^{2}$ Department of Forest Management, Faculty of Forestry, Bogor Agricultural University, Academic Ring Road, Campus IPB \\ Dramaga, Bogor, Indonesia 16680
}

Received June 29, 2015/Accepted September 25, 2015

\begin{abstract}
The periodic comprehensive forest inventory (inventarisasi hutan menyeluruh berkala called IHMB) is Indonesian forest stands inventory which based on compartment at forest effective area of forest management unit (FMU). To preserve sustainable forest management, IHMB implementation are used as a benchmark on the determinate of maximum cutting area and large of timber volume that can be produced by FMU to preparing long-term forest planning. The purpose of this study is to assess the suitability and accuracy of the IHMB implementation results to arranging forest management plan that aims to produce sustainable timber. Data were gathered with direct observation on FMU (PT Bts and PT SMS) in Papua Province. Data analysis using descriptive statistic method and the sampling is using purposive sampling method. The study showed that the data and information collected in accordance with IHMB guidelines have not covered all the necessary data to arranged forest management plans based on the sustainability forest principles to appropriate with the criteria and indicators of sustainability. IHMB Implementation is the important activity on FMU. The sense of word "comprehensive" on IHMB is meaningfully only covered the forest area, without including all components of the data and information on forest ecosystem.
\end{abstract}

Keywords: IHMB, forest management plan, sustainable timber, forest management unit

*Correspondence author, email:f.dorebayo@gmail.com,ph.:+62-8124845870

\section{Introduction}

Forest management and utilization on production forest was carried out by forest management units (FMU) with the realization of indonesian selective cutting and planting system (tebang pilih tanam indonesia called TPTI) ranging from working area setup (penataan areal kerja called PAK) up to harvesting and maintenance. The activities required a good and measurable targets and objective of forest management plans with the systematic activity. Process of arranging forest planning requires of data and information about the potential and physical of forest resources in the area of forest will be managed.

Simon (1987) states that there are some specifications that are most important to purposes of forest inventory that consist of: a) boundary and size of the area that to be inventoried, b) divisions made in the area to be inventoried, c) the nature of the information required, d) presentation of the required information and e) accuracy of the information required. Furthermore Husch et al. (2003), suggests that estimation or assessment of a forest area is very closely connected with the aims to obtain as much possible information of forest resources that exist, which will be relied upon in the decision making, management plans and utilization.
According to the guidelines (MoF 2009), the periodic comprehensive forest inventory (IHMB) is refers to activities of the data and information collection about availability and condition of forest stand, which is held periodically one time in 10 years on all plots of production forest at the management unit. The guidelines explained that IHMB is purpose to determine the timber standing stock, as a basic information to arrange a long term-forest management plans (rencana kerja dan usaha pemanfaatan hasil hutan kayu pada hutan alam called RKUPHHK-HA) and as a substance of a stand increment monitoring on natural forest, plantation forest and production on forest management unit (kesatuan pengelolaan hutan produksi called KPHP).

The potential forest resources estimation have been made with various methods. Tomppo et al. (2008) made with combining national forest inventory field plot and remote sensing data, using geostatistics data (Tiryana 2005), using landsat TM imagery and stand-level field-inventory data (Makela \& Pekkarinen 2004), inventory data and GIS to assess forest characteristic (Westfall \& Morin 2013). Other methods has made to estimation of stand volume are: comparison of point and point-3p sampling (Stamatellos 1995), using physical soil parameters (Lexer \& Honninger 1998), biological criteria and indicators (Miles 2002), the 
variability of stand structure (Muhdin et al. 2008) and stand structure dynamic (Muhdin et al. 2011).

The data and information availability of forest resources have plays an important role to arrange forest management plan, determine the direction and policies of SFM with the aims to sustainable yields and ecosystem. Siry et al. (2005) stated that enhanced SFM will require better reporting and verification more areas covered and enhanced implementation of SFM CI in the future. Furthermore Cotter et al. (2014) using a combination of ecological assessment and economic optimization to design a sustainable land use. Rist and Moen (2013) stated that decision-relevant, sciencebased and solution-oriented approaches are required to tackle future forest management challengers.

Forest management and utilization are currently required to consider the balance of the surrounding ecosystem. Forest management to achieve sustainability yield is more focused on the main goal i.e. timber production sustainability. While the ecosystem based forest management has a broader focus with whole approaching to the stands composition, forest structure, forest functions, site condition, and the ecological factors which aims to maintain and improve the ecosystem ability in the provision of his services while maintaining balance with social and economic factors (Pheng 2000).

Based on the foregoing, there are questions to be answered in this study, i.e.:

1 Does the data that must be collected according to the IHMB guidelines already includes all the data necessary to arrange a forest management plan based on sustainability forest principle in accordance with the criteria and indicators of sustainability?

2 Does the data results on IHMB implementation was already covers the entire data that obtained in according to the IHMB guidelines?

3 Does the data result on IHMB implementation is already appropriate with the data necessary to arranging a longterm forest management plans?

4 Does the forest management by FMU has been using the outcomes data of IHMB?

The study was conducted in May to August 2014 at the FMU PT. Bts at district of Keerom and PT. SMS at district of Sarmi in Papua Province (Figure $1 \& 2$ ). The purpose of this study is to obtain the suitability and accuracy information of the IHMB implementation results to arrange a long-term forest management plans in the framework of forest management with the objective of generating sustainable timber.

\section{Methods}

Time and study site The study was conducted on 2 units of

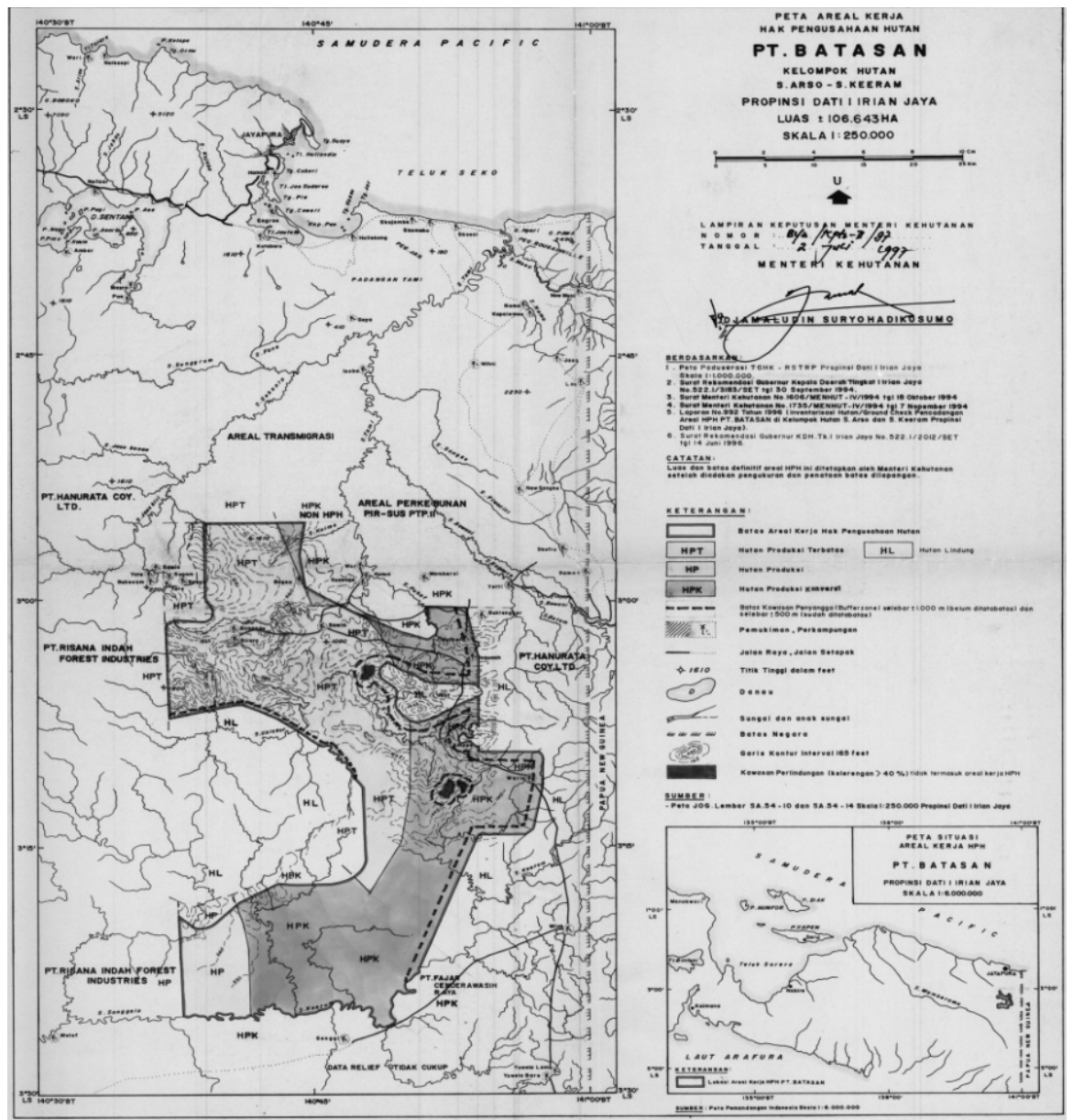

Figure 1 Forest area of PT Bts. 


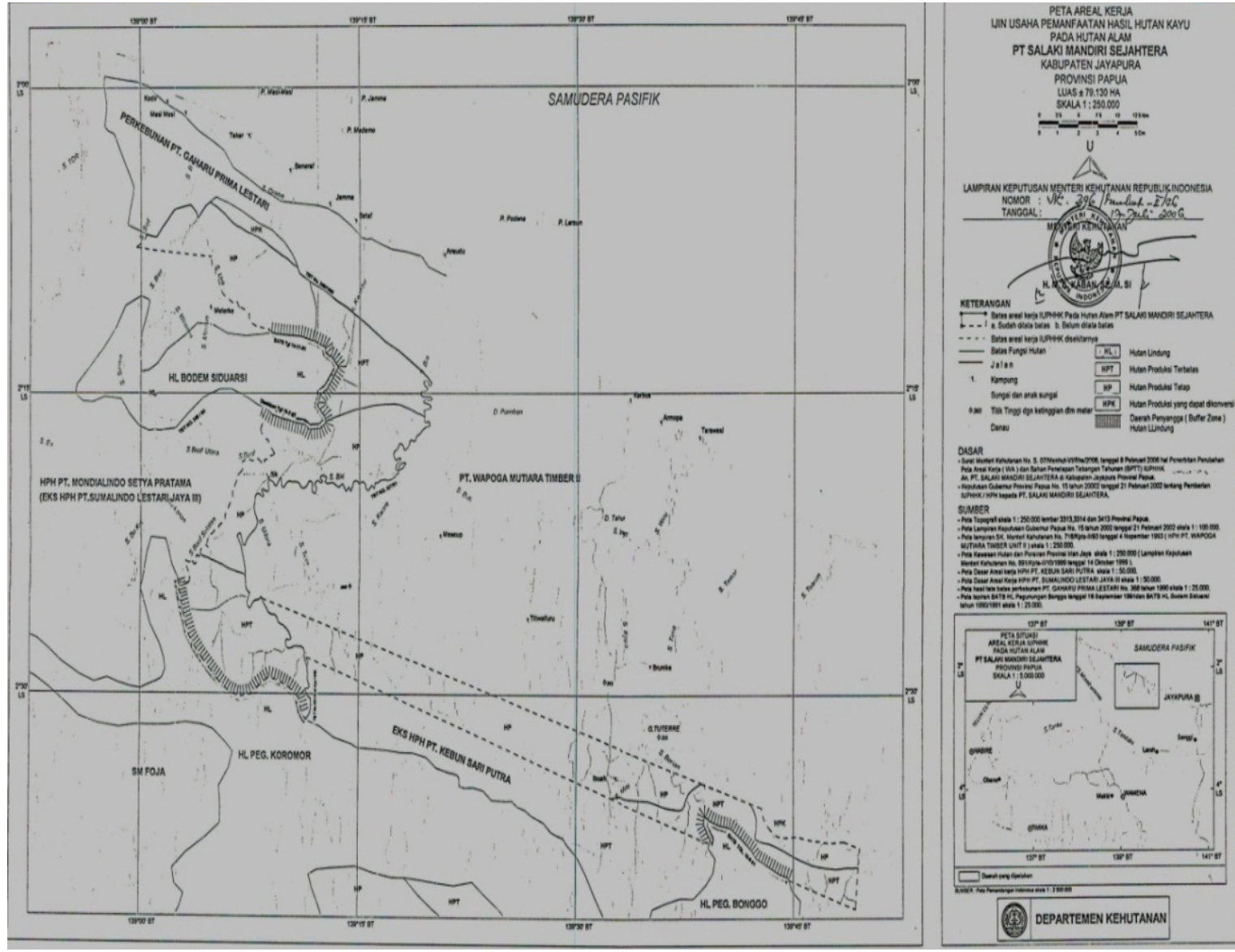

Figure 2 Forest area of PT SMS.

FMU in Papua Province that consist of: PT Bts at Keerom Regency (N2 $55^{\prime}-3^{\circ} 26^{\prime}$ and E140 $\left.37^{\prime}-140^{\circ} 57^{\prime}\right)$ and PT SMS at Sarmi Regency (latitude N02 $00^{\prime}-02^{\circ} 40^{\prime}$ and longitude E138 $\left.50^{\prime}-139^{\circ} 50^{\prime}\right)$. The study was carried out on May to August 2014.

Data collecting The study uses survey method of the data sets on IHMB implementations results, unstructured interviews with IHMB teams, and document collections of IHMB implementations. The data are consist of IHMB implementation report, IHMB verifications report, a longterm forest management plan based on IHMB, current year of short-term forest management plan based on the long-term forest management plan, report of short-term forest management plan by current year, report of indonesian selective cutting and planting system (TPTI) by current year, report of permanent measuring plot, ground survey, standard operational procedure of TPTI activities based on long-term forest management plan and socio-economic report of a local community.

Sampling technique Sampling in this study aims to obtain information and overview the accuracy and suitability of IHMB implementation as well as compliance IHMB's data according to the guidelines by using purposive sampling technique. The basic considerations which form in this study are: for location is selected of FMU in Papua Province where have IHMB implemented and the result are have been evaluated and verification by Forestry Provincial Office and Ministry of Forestry. Next up for the sampling plot is implemented with considerations of: forest cover stratification, accessibility, time, and cost.

At PT Bts verified by 2 IHMB sample plot consisting of plot number 1026024 was located on JJ26 plots (latitude $\mathrm{N} 3^{\circ} 14^{\prime} 005^{\prime \prime}$ and E140 $\left.50^{\prime} 821^{\prime \prime}\right)$, and plot number 1029027 that located on GG29 plots (N3 ${ }^{\circ} 12^{\prime} 540^{\prime \prime}$ and E140 $\left.52^{\prime} 433^{\prime \prime}\right)$. Furthermore on PT SMS verified by 4 IHMB sample plot consisting of plot number 1031047 located on 36AN plots (N2 ${ }^{\circ} 17^{\prime} 994^{\prime \prime}$ and E139 $\left.16^{\prime} 406^{\prime \prime}\right)$, plot number 1031048 located on 35AN plots (N2 $17^{\prime} 505^{\prime \prime}$ and E139 $\left.{ }^{\circ} 16^{\prime} 405^{\prime \prime}\right)$, plot number 1032040 located on $35 \mathrm{AO}$ plots $\left(\mathrm{N} 2^{\circ} 17^{\prime} 31,1^{\prime \prime}\right.$ and E139 $\left.16,5^{\prime} 6,1^{\prime \prime}\right)$ and plot number 1035049 located on 34AR plots with N2 $17^{\prime} 039^{\prime \prime}$ and E139 $18^{\prime} 572^{\prime \prime}$.

Data analysis procedures Data analysis in this study used descriptive statistical methods with descriptive survey approach which aims to describing the circumstances and condition of the subject to be studied. According to Sugiyono (2009), descriptive statistics are the statistic that used to data analyze in a manner describing or overviewing the data has 
been collected without intending to apply the general conclusions. Data analysis steps for assessing the suitability and accuracy of the IHMB implementation are:

1 assessing the accuracy and suitability data result of IHMB implementation according to IHMB guidelines

2 assessing the data suitability of the IHMB guidelines with the CI of sustainability that sets by ITTO and PHPL, and

3 level of IHMB data utilization on the realization of forest management by FMU (Figure 1).

\section{Results and Discussion}

The role of IHMB data to arrange forest management plan The forest management plan is the basic reference of forest management activities which contains objectives, goals, and clear targets that measurable, supported with strategies in its implementation as well as monitoring and evaluation of the plan. Forest management plan requires detailed information about the potential of forest resources data including ecological, geographical conditions, as well as social risks and barriers. IHMB implementation by FMU will generate a potentially standing stocks data that will be relied to arrange a long-term forest management plans.

To provide SFM at the site level, the preparation of forest management plans should be consider of the entire ecosystem landscape while maintaining biological diversity and productivity as well as regeneration ability in sustaining life and its potential to fulfill the functions of the economic, social and ecology, for the current time and future. The facts is, the large number of costs is not comparable with the results obtained in IHMB implementation. That is because the objective of IHMB is only sets to monitoring of forest stands and forest sustainability trend without the monitoring activity of the entire ecosystem supporting components in forest area. So that data and information results on IHMB implementation hasn't been enough to serve as a basis to arrange forest management plans with the objective of generating sustainable timber.

Forest management should be implemented with entirely principle of ecosystem sustainability. The utilization of forest resources by FMU still focused on economics interest without considering the ability of forest support resources and its sustainability in the future. In order to SFM, estimation of potentially forest resources on a forest area should be able to provide regulars information with the focus of aspects: forest resources including forest area and growing stocks, carbon balance, health, and survival ability of forest ecosystem, productivity function including increment and stands are readily to felled, biodiversity, protection function and socio-economic function and conditions (Kohl 2004.)

In the context of SFM at FMU level, IHMB plays a role to providing the data about potentially timber stand based on forest effective area. IHMB implementation expected can be the guidelines by FMU to implementation SFM. The fact is,

Table 1 Data required and the relevance of activity between criteria and indicator (ITTO and PHPL) with IHMB

\begin{tabular}{|c|c|c|c|}
\hline \multicolumn{3}{|c|}{ The relevance of CI with IHMB activities component } & \multirow{2}{*}{ Data requir ed } \\
\hline ITTO & PHPL & IHMB & \\
\hline $\begin{array}{l}\text { Criteria: resource security, indicator: } \\
\text { (b) existence of a management plan }\end{array}$ & $\begin{array}{l}\text { Aspect: production, } \\
\text { indicator (a) long-term } \\
\text { area structuring in SFM }\end{array}$ & $\begin{array}{l}\text { - IHMB implementation } \\
\text { - Sample plot realization } \\
\text { based on compartment }\end{array}$ & $\begin{array}{l}\text { - Potential of forest stand } \\
\text { - RKUPHHK-HA } \\
\text { - RKTUPHHK-HA }\end{array}$ \\
\hline $\begin{array}{l}\text { Criteria: The continuity of timber } \\
\text { production, indicator (a) the } \\
\text { presence of clear, official harvesting } \\
\text { rules, (c) a pre-logging stand } \\
\text { inventory, (d) the number of trees } \\
\text { and/or volume of timber per hectare } \\
\text { harvested, (e) provision for } \\
\text { monitoring the residual growing } \\
\text { stock after logging (f) records of } \\
\text { annual areas cut over time }\end{array}$ & $\begin{array}{l}\text { Aspect: production, } \\
\text { indicator (b) sustainable } \\
\text { harvesting levels for } \\
\text { each type of wood } \\
\text { products, (c) application } \\
\text { of silviculture system to } \\
\text { ensure the regeneration } \\
\text { forest, (e) logging } \\
\text { realization in line with } \\
\text { the plan }\end{array}$ & $\begin{array}{l}\text { - Forest cover stratification } \\
\text { - Sample plot } \\
\text { - Timber standing stocks by } \\
\text { level stakes: pole, small } \\
\text { trees and large trees } \\
\text { - The installation of tree } \\
\text { label }\end{array}$ & $\begin{array}{l}\text { - Potential of forest stand per } \\
\text { diameter classes } \\
\text { - Forest stand after logging } \\
\text { activity } \\
\text { - Forest area has been cleared }\end{array}$ \\
\hline $\begin{array}{l}\text { Criteria: The conservation of flora } \\
\text { and fauna, indicator (b) the extent of } \\
\text { vegetation disturbance after logging }\end{array}$ & $\begin{array}{l}\text { Aspect: ecology, } \\
\text { indicator (c) } \\
\text { management and } \\
\text { monitoring of land and } \\
\text { water impact as a result } \\
\text { of logging activities }\end{array}$ & $\begin{array}{l}\text { - Records of general } \\
\text { information (altitude, } \\
\text { slope, physiography } \\
\text { condition and site } \\
\text { condition) }\end{array}$ & $\begin{array}{l}\text { - Site condition before and } \\
\text { after logging activity } \\
\text { - Forest stand after logging } \\
\text { activity } \\
\text { - Watersheds condition before } \\
\text { and after logging activity } \\
\text { - Impact of logging activities }\end{array}$ \\
\hline $\begin{array}{l}\text { Criteria: planning and adjustment to } \\
\text { experience, indicator (b) } \\
\text { arrangements for forest management } \\
\text { to take into account traditional forest } \\
\text { utilization }\end{array}$ & $\begin{array}{l}\text { Aspect: prerequisites, } \\
\text { indicator (c) the } \\
\text { sufficiency and quantity } \\
\text { of forestry professional } \\
\text { person }\end{array}$ & $\begin{array}{l}\text { - Arranging of IHMB } \\
\text { implementation } \\
\text { - Working team of IHMB }\end{array}$ & $\begin{array}{l}\text { - RKUPHHK-HA } \\
\text { - RKTUPHHK-HA } \\
\text { - The availability of } \\
\text { professional person with } \\
\text { qualification of } \\
\text { GANISPHPL-CANHUT }\end{array}$ \\
\hline
\end{tabular}


in the level of the data needs as well as the relevance between CI (ITTO and PHPL) and IHMB component activities can be used maximally by FMU (Table 1 ).

The availability of potential forest resources data is an important information and it is very usefully on forest management activity. Not only to play a role on arranging the management planning, the data can be used as a basis for the national estimation income (provisi sumber daya hutan dan dana reboisasi called PSDH and DR). In addition, the data can be mapped the diversity species (flora and fauna), ecological, and social, as well as to anticipate the potentially conflict that may occur. Other benefits on availability of the forest resources data are used by Didion et al. (2009) in his research on upland forest in Switzerland is for basal area and the numbering of stands in different classes correction.

The suitability and accuracy of IHMB implementation data result according to the guidelines IHMB implementation data result according to the guidelines is the data that should be generated by FMU in the realization of IHMB implementations. The data are consist of sample plots, timber standing stocks, and general information of the forest including slope, physiographic forest condition, forest tracks condition, cutting years, and information about forest fires (Table 2-Table 7). Based on the report of IHMB implementation by FMU, the Forestry Provincial Office and Ministry of Forestry conducting evaluation and verification of IHMB implementation.

The suitability of IHMB implementation is assessed based on the implementation of IHMB design planning with realizations, as well as realization of the implementations according to the guidelines. Based on result of the study at PT. Bts and PT SMS (FMU), it looks at the actual number of sample plots making the broadly of effective forest area is not comply. FMU has sought to carry out to according with IHMB guidelines, but the realizations are disadvantages and become obstacles on the implementations. The limited number qualified of technical personnel forest planning is one of the factor that affected. The data shows that PT Bts has a working area is about 106.643 ha, with an effective forest area of 88,978 ha. So PT Bts is obligated to make as much as 1,067 sample plots. Based on the ground check, it only realized as much as 4 plots $(0.37 \%)$. Meanwhile, PT SMS has a work area covering 79.130 ha with an effective forest area of $67137 \mathrm{ha}$. So PT SMS is obligated to making as much as 834 of sample plots. Based on the ground check, the actual realized of sample plots is 735 plots $(88.12 \%)$.

The precision on IHMB implementations are assessed by the accuracy of the data and information that generated to according with the guidelines. The precision associated with the means and methods that used to obtain data on timber stand stocking. Measuring capability of the technical person on FMU in the IHMB implementation is highly influential to produce the timber standing stocks data. Based on ground verification of timber standing stocks data in the IHMB sampling plots, measuring of the diameter and free height branches on the study sites is accordance with the real condition of standing stocks (diameter, free height branches, and type). The verification results shows that the amount difference by an average diameter is $2 \mathrm{~cm}$. It is appropriate with research by Kuswandi (2014) which states that the average increment of the dry land forest in Papua Province is about $0.51-0.60 \mathrm{~cm}$ year ${ }^{-1}$.

The periodic comprehensive forest inventory implemented by all FMU in Indonesia based on the guidelines that set by the ministry of forestry. In generally there is no differences in the implementation, it is might be the difference in the implementation by each FMU is in term

Table 2 Standing stock PT Bts

\begin{tabular}{ccrrr}
\hline \multirow{2}{*}{ Diameter $(\mathrm{cm})$} & \multicolumn{2}{c}{ All condition } & \multicolumn{2}{c}{ Commercial } \\
\cline { 2 - 5 } & $\mathrm{N}$ & $\mathrm{V}\left(\mathrm{m}^{3}\right)$ & $\mathrm{N}$ & $\mathrm{V}\left(\mathrm{m}^{3}\right)$ \\
\hline $10 \leq 20$ & $2,526,239$ & $101,049.52$ & $2,526,239$ & $101,049.52$ \\
$20 \leq 30$ & $2,108,191$ & $548,129.27$ & $2,092,617$ & $523,154.16$ \\
$30 \leq 40$ & $1,667,849$ & $1,090,601.78$ & $1,644,850$ & $1,026,879.74$ \\
$40 \leq 50$ & $1,393,761$ & $2,215,876.48$ & $1,390,131$ & $2,114,735.35$ \\
40 up & $2,077,109$ & $5,444,928.86$ & $2,038,067$ & $5,176,454.11$ \\
50 up & 683,348 & $3,229,052.38$ & 647,936 & $3,061,718.76$ \\
\hline
\end{tabular}

$\mathrm{N}=$ total tree of forest productive area, $\mathrm{V}=$ volume of forest productive area

Table 3 Standing stock PT SMS

\begin{tabular}{crrrr}
\hline \multirow{2}{*}{ Diameter $(\mathrm{cm})$} & \multicolumn{2}{c}{ All conditions } & \multicolumn{2}{c}{ Commercial } \\
\cline { 2 - 5 } & \multicolumn{1}{c}{$\mathrm{N}$} & $\mathrm{V}\left(\mathrm{m}^{3}\right)$ & $\mathrm{N}$ & $\mathrm{V}\left(\mathrm{m}^{3}\right)$ \\
\hline $10 \leq 20$ & $24,521,014$ & $3,904,429.71$ & $23,110,957$ & $3,681,758.59$ \\
$20 \leq 30$ & $5,278,981$ & $2,438,898.60$ & $5,071,620$ & $2,344,439.87$ \\
$30 \leq 40$ & $3,634,541$ & $3,160,206.45$ & $3,465,814$ & $3,007,304.54$ \\
40 up & $3,414,170$ & $7,854,309.31$ & $2,838,448$ & $6,539,734.96$ \\
50 up & $1,584,851$ & $5,091,050.38$ & $1,314,016$ & $4,235,135.01$ \\
60 up & 835,207 & $3,434,061.45$ & 685,209 & $2,838,083.26$ \\
\hline
\end{tabular}

$\mathrm{N}=$ total tree of forest productive area, $\mathrm{V}=$ volume of forest productive area 
Table 4 Soil texture of PT Bts and PT SMS

\begin{tabular}{lcc}
\hline \multirow{2}{*}{ Soil texture } & PT Bts & PT SMS \\
\cline { 2 - 3 } Sand & $\%$ & $\%$ \\
Argillaceous sand & - & - \\
Clays of sandy & - & - \\
Clays sandy loam & 87 & 1.65 \\
Sandy ofloamy & 10 & 0.70 \\
Clayey & 1 & 0.30 \\
Loamy of clay & - & 3.60 \\
Loam & 2 & 49.10 \\
Dusty clay & - & 11.00 \\
Dusty loamy & - & 23.30 \\
Dust & - & 9.73 \\
\hline$\quad$ Total & - & - \\
\hline
\end{tabular}

Table 6 Forest cover condition of PT Bts and PT SMS

\begin{tabular}{|c|c|c|}
\hline \multirow{2}{*}{ Vegetation cover } & PT Bts & PT SMS \\
\hline & $\%$ & $\%$ \\
\hline Primary forest & 40 & 74 \\
\hline Secondary forest & 57 & 24 \\
\hline Swamp forest & - & - \\
\hline \multirow[t]{2}{*}{ Non forest acreage } & 3 & 2 \\
\hline & 100 & 100 \\
\hline
\end{tabular}

of preparation and assignment tools in the form of tree height curve and volume table, which were prepared using regression analysis with significance testing analysis of variance. It is because the determination of tools adapted to the needs of each FMU and its standing stock condition.

PT Bts compiled the tree height curve for this type of Dipterocarpaceae and Mixwood by using 99 sample trees and 46 trees for validation of models (free branch height and total height). While the set of volume table of Dipterocarpaceae and Mixwood also uses 99 sample trees and 46 trees for validation of models. For the volume table PT Bts sets the local volume table based on the results of data analysis because there were close relationship between free height branch and the diameter at breast height $(d b h)$, so that in the preparation of volume table used just one variable i.e. diameter at breast height only. Results of regression analysis indicates that the selected models that are used in the sets of a tree height curve for free height branch and the total height is $\mathrm{T}=\mathrm{a}+\mathrm{bD}+\mathrm{cD}^{2}$, while for drafting table volume is $\mathrm{V}=\mathrm{aD}^{\mathrm{b}}$ as shown in Equation [1], Equation [2], Equation [3], Equation [4], Equation [5], and Equation [6].

Free height-branch of:

Dipterocarpaceae

$\mathrm{T}=9.9845517+0.1121368 \mathrm{D}-0.0001 \mathrm{D}^{2}$

Mixwood

$\mathrm{T}=8.1449227+0.1623175 \mathrm{D}-0.0003 \mathrm{D}^{2}$

Total height of:

Dipterocarpaceae

$\mathrm{T}=13.5129767+0.1863061 \mathrm{D}-0.0006 \mathrm{D}^{2}$
Table 5 Site conditions of PT Bts and PT SMS

\begin{tabular}{lcc}
\hline \multirow{1}{*}{ Site } & PT Bts & PT SMS \\
\cline { 2 - 3 } & $\%$ & $\%$ \\
\hline None & 100 & 66.1 \\
Stony & - & 22.2 \\
Swamp & - & 1.4 \\
Labile & - & 10.3 \\
\hline Total & 100 & 100 \\
\hline
\end{tabular}

Table 7 Physiography condition of PT Bts and PT SMS

\begin{tabular}{lcc}
\hline \multirow{2}{*}{ Physiography } & PT Bts & PT SMS \\
\cline { 2 - 3 } & $\%$ & $\%$ \\
\hline Flat & 32 & 77.2 \\
Wavy & 64 & 20.2 \\
Mountain peaks & 1 & 0.5 \\
Upward slope & - & 0.4 \\
Middle slope & 2 & 1.1 \\
Lower slope & 1 & 0.5 \\
Valley & - & \\
Steep & - & 0.1 \\
\hline Total & 100 & 100 \\
\hline
\end{tabular}

Mixwood

$\mathrm{T}=12.5134625+0.1968824 \mathrm{D}-0.0005 \mathrm{D}^{2}$

Volume tables of dipterocarpaceae

$\mathrm{D}=0.000265246 \mathrm{D}^{2,2901}$

Mixwood

$\mathrm{D}=0.000133755 \mathrm{D}^{2,4766}$

PT SMS composing tree height curve and volume tables by classifying species into Dipterocarpaceae and non Dipterocarpaceae, with the number of tree is 150 to construct the height curve (100 samples and 50 for validation) and 400 trees to construct volume table that consists 200 trees of Dipterocarpaceae type and 200 trees for non Dipterocarpaceae (each 150 for samples and 50 for validation). PT SMS composing the local volume table based on the results of the data analysis showed that there is a close relationship between $d b h$ and free height branch, so using variable diameter at breast height. The results of the regression analysis indicates that the selected models that are used in the preparation of free height branch and total height is $\ln \mathrm{T}=\ln \mathrm{a}+\mathrm{b} \ln \mathrm{D}$. Preparation of volume table for Dipterocarpaceae using the equations $\mathrm{T}=\mathrm{a}+\mathrm{bD}^{2}$, non Dipterocarpaceae using $\ln \mathrm{T}=\ln \mathrm{a}+\mathrm{b} \ln \mathrm{D}$ and for the combined species (Dipterocarpaceae and non Dipterocarpaceae) is $\mathrm{T}=\mathrm{a}+\mathrm{bD}^{2}$, with the model of following equations are:

Free height branch:

dipterocarp $\mathrm{T}=3.419400033 \mathrm{D}^{0,379263978}$

non dipterocarp $\mathrm{T}=3.518612679 \mathrm{D}^{0,372906451}$ 
combined species $\mathrm{T}=8.588918438 \mathrm{D}^{0,27100591}$

Volume table:

dipterocarp $\mathrm{D}=0.091852013+0.000706777 \mathrm{D}^{2} \quad$ [10]

non dipterocarp $\mathrm{D}=0.000211277 \mathrm{D}^{0,2300126785}$

combined species $\mathrm{D}=0.000146099+0.000744848 \mathrm{D}^{2} \quad[12]$

The success of IHMB implementation depends on the availability and the responsibility of technical personel in the ground. These things have an impact on the economic value that may be obtained by the company. Timber volumes are common measure of inventory and output use in a forest management plan. It is also directly related to revenue, and thus are intimately tied to the economic evaluation of activities (Bettinger et al. 2009).

The role of IHMB data result on forest management realization Production forest management by FMU in Indonesia is implemented with the silvicultural system based on harvesting system that consist of selective cutting and clear cutting. The Indonesian selective cutting and planting system (TPTI) is a series activities that have been planned on short-term forest management by FMU. IHMB implementation results data and information of potentially standing stocks based on the diversity in a forest area. Realization of forest management by FMU, harvest activity implemented based on the results of the stands inventory before cutting (inventarisasi tegakan sebelum penebangan called ITSP) with $100 \%$ sampling intensity that carried out 2 years earlier.

Based on the results of IHMB implementation, PT Bts has a maximum cutting area covering 28.945 ha 10 years $^{-1}$ or

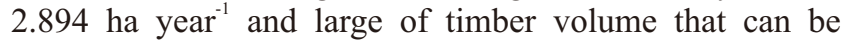
produce are $1.226 .446 \mathrm{~m}^{3} 10$ years $^{-1}$ or $126.544,6 \mathrm{~m}^{3}$ year ${ }^{-1}$. While PT SMS has a maximum cutting area covering 30.042 ha 10 years $^{-1}$ or 3.042 ha year $^{-1}$ and large of timber volume that can be produced are $1.456 .809 \mathrm{~m}^{3} 10$ years ${ }^{-1}$ or $145.680,9 \mathrm{~m}^{3}$ year $^{-1}$. In fact implementation of short-term forest management (rencana kerja dan usaha pemanfaatan hasil hutan kayu pada hutan alam called RKTUPHHK-HA) by both PT Bts and PT SMS at the time of 2012 and 2013, the timber production quantities are not reaching the target in accordance with the results data of IHMB implementation (Table 8).

Forest management realization by FMU is the stage implementation of RKTUPHHK-HA activity that have been arranged. The stages in RKTUPHHK-HA is the elaboration of TPTI silvicultural system as well established by MoF. According to Nieuwenhuis (2010) silvicultural system is a plan that cover all treatment of forest stand forms in order to achieve stand structure goals based on the entire goals of forest management. IHMB implementation results used to determine the amount of forest stand volume that can be harvested. Furthermore the harvesting realization is implemented based on results of ITSP with attention to limits or quantity of forest stand that have been defined by IHMB results.

The fact is, operationally activity realization by FMU does not accordance with the plans is something unusual going on. The factor that causes is that the monitoring and evaluation of forest management plans is not implemented by FMU at the time when execution of operationally activity is running. Bettinger et al. (2009) stated that in generally operational plans in the activity of natural resources management is made up of several stages which are:

1 identification of potentially natural resources,

2 set up goals and objectives of management,

3 impact evaluations of alternative management strategies,

4 select and apply the alternative management plans in order to objectives achievement and reduce the impact of environment, and

5 monitoring the effectiveness of the plans.

The achievement of sustainable forest management (SFM) needed some components of activity and the government commitments to support each other, that all must be participate fully in the same time. The government's commitment to set a policy related to the potentially of forest resources information should be able to implemented with clear goals and measurable, than the results is accountable. In addition, the clarity of forest area status, forest management plan, technical and methods determination of silvicultural system that will be used, harvesting, forest protection, environmental impacts, economical factors, research, and development including relationship with the local community must be available on high priority before implemented by FMU. The availability of all information is expected to be the guidelines on forest management with main objective to SFM achievement (ITTO 1992).

Based on CI sets by ITTO and PHPL, not all of the CI appropriated to the IHMB component activities. Furthermore, the availability data of IHMB implementation

Table 8 The planning and realization of wood production RKUPHHK

\begin{tabular}{|c|c|c|c|}
\hline \multicolumn{4}{|c|}{ Result data of IHMB implementation } \\
\hline \multicolumn{2}{|c|}{ PT Bts } & \multicolumn{2}{|c|}{ PT SMS } \\
\hline \multicolumn{2}{|c|}{ Production per year $\left(\mathrm{m}^{3}\right)$} & \multicolumn{2}{|c|}{ Production per year $\left(\mathrm{m}^{3}\right)$} \\
\hline \multicolumn{2}{|c|}{$126,544.6$} & \multicolumn{2}{|c|}{$145,680.9$} \\
\hline \multicolumn{4}{|l|}{ Result data of ITSP } \\
\hline \multicolumn{2}{|c|}{ Production planning $\quad\left(\mathrm{m}^{3}\right)$} & \multicolumn{2}{|c|}{ Production planning $\left(\mathrm{m}^{3}\right)$} \\
\hline Year of 2012 & Year of 2013 & Year of 2012 & Year of 2013 \\
\hline $122,243.91$ & $123,245.67$ & $73,343.76$ & $75,265.86$ \\
\hline Produc & $\left(\mathrm{m}^{3}\right)$ & Produ & $\left(\mathrm{m}^{3}\right)$ \\
\hline Year of 2012 & Year of 2013 & Year of 2012 & Year of 2013 \\
\hline $13,434.39$ & $12,669.38$ & $23,131.06$ & $40,764.35$ \\
\hline
\end{tabular}


cannot cover all the data needs according to CI. The availability data of IHMB implementation on FMU is not yet to developing the whole information about forest ecosystem to be managed. In case of forest management realization by FMU, data and information of timber standing stocks, land cover condition, river basin condition after harvesting activity is not available. So the data and information about forest ecosystem that needs to reach SFM which will be uses as a base to monitoring and evaluating is not completely available.

\section{Conclusion}

The data and information collected in accordance with IHMB guidelines have not covered all the necessary data to arranged forest management plans based on the sustainability forest principles to appropriate with the criteria and indicators of sustainability. The sense of word "comprehensive" on IHMB is meaningfully only covered the forest area, without including all components of the data and information on forest ecosystem. Forest inventory is essentially an activity that should be implemented by the government as the owner right over of forest area. The results data of IHMB implementation are used as a benchmark on the determination of maximum cutting area and large of timber volume that can be produced by FMU in order to preparing RKUPHHK-HA and RKTUPHHK-HA. Meanwhile realization of the forest management on FMU is based on implementation of the stages activity by silvicultural system (TPTI).

\section{References}

Bettinger P, Boston K, Siry JP, Grebner DL. 2009. Forest Management and Planning. Oxford: Elsevier Inc.

Cotter M, Berkhoff K, Gibreel T, Ghorbani A, Golbon R, Nuppenau E-A, Sauerborn J. 2014. Designing a sustainable land use scenario based on a combination of ecological assessments and economic optimization. Ecological Indicators:36:779-787. http://dx.doi.org/10. 1016/j.ecolind.2013.01.017.

Didion M, Kupferschmid AD, Lexer MJ, Rammer W, Seidl R, Bugmann H. 2009. Potentials and limitations of using large-scale forest inventory data for evaluating forest succession models. Ecological Modelling 220:133-147. http://dx.doi.org/10.1016/j.ecolmodel.2008.09.021.

Husch B, Beers TW, Kershaw JA. 2003. Forest Mensuration $4^{\text {th }}$ edition. New Jersey: John Wiley \& Sons. Inc.

[ITTO] International Timber Trade Organization. 1992. Criteria for The Measurement of Sustainable Tropical Forest Management. Yokohama: ITTO Policy Development Series 3.

Kuswandi R. 2014. Formulasi Dinamika Pertumbuhan Hutan Alam Lahan Kering di Papua. Sintesa Rencana Penelitian Integratif 2010-2014. Bogor: Badan Penelitian dan Pengembangan Kehutanan.

Lexer MJ, Hönninger K. 1998. Estimating physical soil parameters for sample plots of large-scale forest inventories. Forest Ecology and Management. 111:231-247. http://dx.doi.org/10.1016/S0378-1127 (98)00335-1.

Mäkelä H, Pekkarinen A. 2004. Estimation of forest stand volumes by Landsat TM imagery and stand-level fieldinventory data. Forest Ecology and Management 196:245-255. http://dx.doi.org/10.1016/j.foreco. 2004.02.049.

Miles, PD. 2002. Using biological criteria and indicators to address forest inventory data at the state level. Forest Ecology and Management 155:171-185. http://dx.doi. org/10.1016/S0378-1127(01)00557-6.

[MoF] Ministry of Forestry. 2009. Peraturan Menteri Kehutanan Republik Indonesia Nomor: P.33/MenhutII/2009 tentang Pedoman Inventarisasi Hutan Menyeluruh Berkala (IHMB) Pada Usaha Pemanfaataan Hasil Hutan Kayu Pada Hutan Produksi. Jakarta: Ministry of Forestry.

Muhdin, Suhendang S, Wahjono D, Purnomo H, Istomo, Simangunsong BCH. 2008. The variability of stand structure of logged-over natural forest. Jurnal Manajemen Hutan Tropika (2):81-87.

Muhdin, Suhendang S, Wahjono D, Purnomo H, Istomo, Simangunsong BCH. 2011. Estimation of stand structure dynamics of logged-over natural forests. Jurnal Manajemen Hutan Tropika (1):1-9.

Nieuwenhuis M. 2010. Terminology of forest management $2^{\text {nd }}$ revised edition. IUFRO World Series Vol. 9-English. Vienna: IUFRO Headquarters.

Peraturan Direktur Jenderal Bina Usaha Kehutanan Nomor: P.8/VI-BPPHH/2012 tentang Standar dan Pedoman Pelaksanaan Penilaian Kinerja Pengelolaan Hutan Produksi Lestari dan Verifikasi Legalitas Kayu. Jakarta.

Pheng C. 2000. Understanding the role of forest simulation models in sustainable forest management. Environmental Impact Assessment Review 20:481-501. http://dx.doi. org/10.1016/S0195-9255(99)00044-X.

Rist L, Moen J. 2013. Sustainability in forest management and a new role for resilience thinking. Forest Ecology and Management 310:416-427. http://dx.doi.org/10.10 16/j.foreco.2013.08.033.

Simon H. 1987. Manual Inventore Hutan. Jakarta: UI Press.

Siry JP, Cubbage FW, Ahmed MR. 2005. Sustainable forest management: global trends and opportunities. Forest Policy and Economics 7:551-561. http://dx.doi.org/10. 1016/j.forpol.2003.09.003.

Stamatellos GS. 1995. Comparison of point and point-3P sampling for forest volume estimation with cost analysis. Forest Ecology and Management 74:75-79. http://dx. 
doi.org/10.1016/0378-1127(94)03511-T.

Suhendang E. 1997. Determining of the optimum measurement period for permanent sample plot in dry land natural forest. Jurnal Manajemen Hutan Tropika 3(1):1-13.

Tiryana T. 2005. Predicting spatial distrribution of stand volume using geostatistics. Jurnal Manajemen Hutan Tropika 11(2):15-27.
Tomppo E, Olsson H, Ståhl G, Nilsson M, Hagner O, Katila M. 2008. Combining national forest inventory field plots and remote sensing data for forest databases. Remote Sensing of Environment 112:1982-1999. http://dx.doi. org/10.1016/j.rse.2007.03.032.

Westfall JA, Morin RS. 2013. A cover-based method to assess forest characteristics using inventory data and GIS. Forest Ecology and Management 298:93-100. 